\title{
Bridging between litterbags and whole-ecosystem experiments: a new approach for studying lake sediments
}

\author{
Andrew J. TANENTZAP, ${ }^{1 *}$ Erik J. SZKOKAN-EMILSON,${ }^{1}$ Cyndy M. DESJARDINS,${ }^{1}$ Chloe ORLAND,${ }^{1}$ \\ Kurt YAKIMOVICH, ${ }^{2}$ Randy DIRSZOWSKY, ${ }^{2}$ Nadia MYKYTCZUK,,${ }^{2}$ Nathan BASILIKO, ${ }^{2}$ John GUNN ${ }^{2}$
}

${ }^{1}$ Ecosystems and Global Change Group, Department of Plant Sciences, University of Cambridge, Downing Street, Cambridge CB2 3EA, UK; ${ }^{2}$ Laurentian University, 935 Ramsey Lake Road, Sudbury P3E 2C6, Ontario, Canada

*Corresponding author: ajt65@cam.ac.uk

\begin{abstract}
Nearshore sediments have a major influence over the functioning of aquatic ecosystems, but predicting their response to future environmental change has proven difficult. Previous manipulative experiments have faced challenges controlling environmental conditions, replicating sediment mixing dynamics, and extrapolating across spatial scales. Here we describe a new approach to manipulate lake sediments that overcomes previous concerns about reproducibility and environment controls, whilst also bridging the gap between smaller microcosm or litterbag experiments and whole-ecosystem manipulations. Our approach involves submerging moderate-sized $(\sim 15 \mathrm{~L})$ artificial substrates that have been standardised to mimic natural sediments within the littoral zones of lakes. We show that this approach can accurately mirror the absolute dissolved organic carbon concentrations and $\mathrm{pH}$ of pore water, and to a lesser degree inorganic carbon concentrations, from natural lake sediments with similar organic matter profiles. On a relative basis, all measured variables had similar temporal dynamics between artificial and adjacent natural sediments. Late-summer zooplankton biomass also did not differ between natural and artificial sediments. By offering a more realistic way to manipulate freshwater sediments than previously possible, our approach can improve predictions of lake ecosystems in a changing world.
\end{abstract}

Key words: Carbon cycling; food webs; lake sediments; terrestrial-aquatic linkages; scaling.

Received: October 2016. Accepted: January 2017.

\section{INTRODUCTION}

Freshwater sediments, particularly the top few centimetres in nearshore environments, are of key importance to global biogeochemical cycles and aquatic food webs because they are sites where large amounts of organic matter $(\mathrm{OM})$ are transformed and mineralised (Wetzel, 2001). Annually, lake sediments are a sink for up to $0.6 \mathrm{Pg}$ carbon (C) year ${ }^{-1}$ (Tranvik et al., 2009), and emit around 0.05 and 0.2-1.2 Pg C ( $\mathrm{CO}_{2}$-equivalents) of $\mathrm{CO}_{2}$ and $\mathrm{CH}_{4}$, respectively (Bastviken et al., 2004; Pace and Prairie, 2005). The high levels of OM processing consequently allow lake sediments to host phototrophic algal, bacterial, and fungal communities that can be many times more productive than in open waters (Fischer and Pusch, 2001; Vadeboncoeur et al., 2002; Ask et al., 2009; Wurzbacher et al., 2010). Additionally, nutrient exchange between decomposing surface sediments and overlying waters promotes harmful algal blooms and contaminant release in human-impacted waters that can further influence food webs (Eggleton and Thomas, 2004; Carpenter, 2005).

Experiments provide a controlled way of predicting how sediment functioning might respond to future changes in OM inputs. Here we introduce a new experimental approach to bridge the gap between smaller microcosm or lit- terbag experiments and whole-ecosystem manipulations. The approach involves submerging containers with moderate-sized ( $\sim 15 \mathrm{~L})$ artificial sediments, informed by geochemical surveys of natural ecosystems, within real lakes. Our work builds upon a recent technique described by Orihel and Rooney (2012) by offering the potential to link finescale geochemical studies with large-scale ecological studies of entire communities. Ecological studies have rarely manipulated sediments that have been standardised to mimic natural conditions, despite this strategy being fundamental to fields such as environmental toxicology (Suedel and Rodgers, 1994; but see Feuchtmayr et al., 2009). Traditionally, studies have added OM either to fieldcollected sediments, which have been relocated to laboratories or outdoor mesocosms (Wood and Richardson, 2009; Liboriussen et al., 2011; Song et al., 2013), or in situ by burying decomposing leaves into sediment surfaces (Herbst, 1980; Jackson et al., 1995; Longhi et al., 2008; Costantini et al., 2009; Marmonier et al., 2010).

Our new experimental platform has at least three major advantages over previous methods for manipulating freshwater sediments. First, our approach permits a level of reproducibility that is unachievable in experiments that simply manipulate field-collected samples and are limited by pre-existing $\mathrm{OM}$, i.e. OM can be added but never sub- 
tracted from natural sediment. In situ experiments also cannot control the many parameters that vary horizontally across surface sediments at fine spatial scales (i.e. $<10 \mathrm{~m}$ ), such as geochemical composition (Korsman et al., 1999; Yu et al., 2015). By contrast, relocating field-collected sediments to new settings, such as the laboratory, may fail to replicate in situ conditions (Orihel and Rooney, 2012). Second, our approach offers a more realistic simulation of long-term mineralisation and decomposition processes than, for example, leaf litterbags, which have been widely used to study biogeochemistry and ecosystem metabolism (Herbst, 1980; Jackson et al., 1995; Longhi et al., 2008; Costantini et al., 2009). As an OM amendment, litterbags often sit flush on the sediment surface and are not directly incorporated into sediment profiles. Mesocosms similarly isolate experimental units on shore and away from natural waters, e.g. in cattle tanks. Isolation in each method is problematic because it prevents mixing with sediments and overlying surface waters, respectively, which may be important for processes such as oxidation and nutrient recycling. Finally, our approach is sufficiently large and designed in such a way that it allows continuous monitoring of geochemistry and biotic communities that would not be possible with other methods. Lab and litterbag experiments are also often $\leq 0.04 \mathrm{~m}^{2}$ in size, so may have limited value for broader ecosystem-level generalisations. The only studies performed at a whole-ecosystem level have focused on removing entire sediment horizons, such as for lake restoration or fisheries management, without manipulating OM directly (Peterson, 1982). New approaches are therefore needed to manipulate natural sediments over large spatial scales.

\section{Sediment boxes: creating a new world within lake benthic zones}

We originally developed our sediment incubation approach to study linkages between terrestrial and aquatic ecosystems. Our interest was in manipulating the quantity and quality of terrestrial organic matter ( $\mathrm{tOM}$ ) that accumulated in littoral sites under different water qualities. Previously, we discovered that the productivity of bacteria, zooplankton, and young-of-the-year fish in a single lake environment was greater beneath catchments that received larger inputs of tOM (Tanentzap et al., 2014). We were subsequently interested in testing how tOM was processed and mobilized into aquatic food webs at much greater resolution. The incubation approach therefore offered numerous advantages over our observational studies, not the least of which was the ability to control for variation in the delivery and processing of OM by catchments with different geomorphologies.

The premise of our sediment boxes involved mixing inorganic and organic substrates within containers that were submerged in the bottom of a common lake environ- ment. We used 17.5-L (surface area: $0.19 \mathrm{~m}^{2}$, depth: 0.13 $\mathrm{m})$ open-top high-density polyethylene (HDPE) containers, as these could be replicated at high number and easily manoeuvred when waterlogged. In principle, the HDPE containers could be much larger. For example, we tried preparing $365 \mathrm{~L}$ containers, but were constrained by the availability of organic materials and weight of inorganic substances. Here, we outline the setup of our sediment boxes with integrated biogeochemical samplers, describe how we prepared a sediment material that mimicked the natural environment, and present some potential data that can be generated using this approach.

\section{Box preparation}

We made three important modifications to each HDPE container (Fig. 1a). First, we wanted to ensure mixing of the sediment bottom with the external environment, partly to avoid artificially promoting anoxic conditions. We therefore drilled nine 8-mm holes in the bottom of each container to ensure that the mesocosms were freely draining. Second, we wanted to sample sediment pore water at high resolution, so we permanently secured a $3-\mathrm{mL}$ polypropylene syringe immediately beneath the sediment surface along one side of the HDPE container. The syringe was placed horizontally in the upper $1 \mathrm{~cm}$ of sediment, with the wall facing the sediment partially removed and covered in ca. $250 \mu \mathrm{m}$ nylon mesh to avoid clogging (Fig. 1b). This sampler is effectively analogous with other methods for measuring pore water, such as dialysis (Carignan, 1985) or suction (Bertolin et al., 1995) samplers, and studies interested in vertical profiling can of course layer syringes at different depths in the sediment. To each syringe, we connected nylon tubing (inside diameter: $3.2 \mathrm{~mm}$, outside diameter: $4.8 \mathrm{~mm}$ ), which met a float on the water surface and allowed us to sample without disturbing the lake bottom. Finally, we attached light and temperature loggers and customised redox probes (Swerhone et al., 1999) to as many boxes as possible.

\section{Sediment mixture}

Here we outline how we created a sediment with 5\% tOM on a dry weight basis to mimic the natural conditions in Lake Laurentian, Ontario, Canada $\left(46^{\circ} 27^{\prime} 30^{\prime \prime} \mathrm{N}\right.$, $\left.80^{\circ} 56^{\prime} 0^{\prime \prime} \mathrm{W}\right)$. Lake Laurentian is a small ( $157 \mathrm{ha}$ area, 5.2 $\mathrm{m}$ maximum depth) circumneutral lake with relatively high dissolved organic carbon (DOC) concentrations around $7 \mathrm{mg} \mathrm{L}^{-1}$. The lake is surrounded by boreal forest and located in a 970-ha conservation area with little contemporary human disturbance aside from hiking and skiing trails.

Our artificial sediment was prepared by mixing organic and inorganic particles to mimic size fractions and vertical structuring observed in a survey of nearshore lake 
sediments with varying tOM inputs from adjacent streams (Supplementary Text). First, we mixed $0.25 \mathrm{~kg}$ of each of deciduous (primarily Acer rubrum, Betula papyrifera, Populus tremuloides, Quercus spp.) and coniferous (Pinus spp.) litterfall representative of the surrounding forest, where these two tree types occurred in relatively equal proportions. Litterfall had been air-dried at ca. $25^{\circ} \mathrm{C}$ over at least 7 days to a constant mass. Air-drying ensured no chemical and physical changes occurred from exposing material to higher temperatures $\left(e . g .>50^{\circ} \mathrm{C}\right)$, thereby better reflecting natural processes. We sorted dried litterfall into $<1$ and $1-10 \mathrm{~mm}$ diameter fractions at a 3:7 ratio to reproduce average fragment sizes observed in the natural sediments (Supplementary Fig. S1).

Next, the tOM was homogenously mixed with $9.5 \mathrm{~kg}$ of minerogenic material consisting of clay/silt, fine sand, and sand/gravel $(<0.063 \mathrm{~mm}, 0.063-1 \mathrm{~mm},>1 \mathrm{~mm}$ diameter particles, respectively), which was sourced from a local quarry. As our interest was in testing the effects of different tOM on sediment dynamics, we pre-mixed the clay/silt, fine sand, and sand/gravel fractions into a constant 2:5:3 ratio by dry-weight, respectively, to reproduce conditions seen in one of our sampling sites (site J; Supplementary Fig. S1). We chose site J, despite variability in composition among sites (Supplementary Fig. S1), because its relatively large size (area of stream-lake confluence zone $=359 \mathrm{~m}^{2}$; catchment area $\left.=39 \mathrm{ha}\right)$ and gentle slope (mean catchment slope \pm standard deviation [SD] from a 10 -m digital elevation model: $5.6 \pm 4.2^{\circ}$ ) were typical of geomorphology in the wider region (Rasmussen et al., 1989). Moreover, we wanted to avoid high concentrations of clay/silt and fine sand that were less indicative of fluvial transport of tOM (Håkanson and Jansson, 1983). The final sediment mixture was then laid upon $7 \mathrm{~kg}$ of crushed granitic rock (ca. $2 \mathrm{~mm}$ diameter) and filled to a height of $0.08 \mathrm{~m}$ in each mesocosm (Fig. 1c). There was also no clear evidence of vertical structuring of organic matter or particle size in the top $10 \mathrm{~cm}$ of our natural sediment survey (Supplementary Fig. S1), so we did not incorporate such variation into our design. Lake sediments
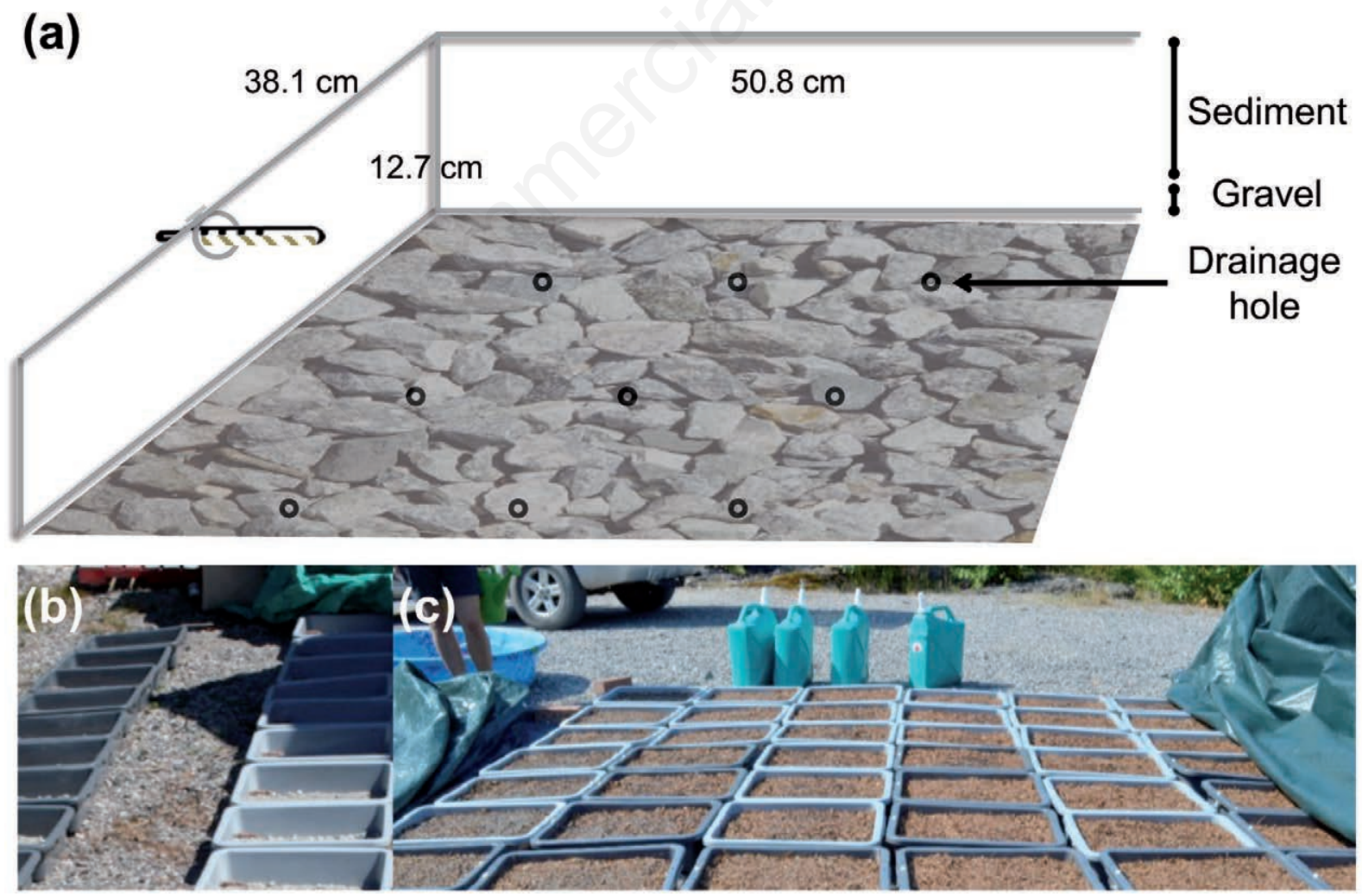

Fig. 1. Photo of experimental sediment boxes. a) Schematic drawn to scale (dimensions shown) of a sediment box, drainage holes, and sampling syringe with bottom wall exposed and wrapped in nylon mesh (denoted by hatched bars); the box is underlain by larger granitic bedrock and filled with artificial sediment consisting of a homogenous mixture of inorganic and organic material; the syringe is fastened with nylon cable ties onto a 64-mm nylon bolt drilled through the box lip; temperature-light loggers are also attached to the bolt with nylon cable ties. b) Boxes with granitic bedrock and drainage holes. c) Boxes filled with sediment containing progressively more tOM from left to right. 
typically vary in their vertical structure over much greater depths than studied here because surface mixing dissipates (Håkanson and Jansson, 1983).

Finally, a $1 \mathrm{~mm} \times 1 \mathrm{~mm}$ nylon mesh was affixed to the top of each mesocosm to limit physical disturbance and provide standardised shading. Each box was then soaked for 5 to 7 days with Lake Laurentian water to ensure that the tOM became waterlogged and settled (Hoover et al., 2010). We further minimised physical disturbance during initial lake installation by temporarily attaching HDPE lids to each container for 24-48 hours. After 1 month in the lake, we made an 80-mm wide slit in the centre of each mesh to promote colonisation by organisms larger than 1 $\mathrm{mm}$ in size.

\section{Anchoring sediment boxes to the real world}

Although our sediment boxes were constructed based upon detailed surveys of natural sediments, a key question is whether they functioned as in nature. To test this, we first compared pore water from natural surface sediments in Lake Laurentian to sediment boxes that were installed in the littoral zone between $22^{\text {nd }}$ and $23^{\text {rd }}$ July 2015 at a depth of ca. $0.5 \mathrm{~m}$. Pore water samples were taken from the upper $1 \mathrm{~cm}$ of the natural sediments (hereafter 'lake bottom samples') by permanently installing one of our modified syringe samplers adjacent to each of three sediment boxes. The sediment boxes were built as described in the previous section $(5 \%$ tOM) so as to mirror the mean $\mathrm{OM}$ content $\pm \mathrm{SD}$ associated with the lake bottom samples of $3.9 \pm 0.8 \%$. After 14 months, the sediment boxes still had a mean $\mathrm{OM}$ content $\pm \mathrm{SD}$ of $5.9 \pm 2.2 \%$.

Pore water samples were collected approximately every 3 days for two weeks from the lake bottom and sediment boxes for our comparison. The samples were collected 14 months after the initial installation. Each sampling syringe was connected to $122 \mathrm{~cm}$ of nylon tubing that was purged of water prior to extracting $45 \mathrm{~mL}$ of pore water into duplicate $60 \mathrm{~mL}$ syringes at the lake surface. To measure DOC, we filtered one of the samples through a $0.5 \mu \mathrm{m}$ glass fibre filter (Macherey-Nagel MN $85 / 90$ ) and into a $20-\mathrm{mL}$ scintillation vial pre-acidified with $125 \mu \mathrm{l}$ of $4 \mathrm{~N} \mathrm{HCl}$. Samples were then run in NPOC mode on a Shimadzu TOC5000A analyser. We used the other pore water sample to measure total inorganic carbon (TIC) and $\mathrm{CO}_{2}$ concentrations. We acidified the second $45 \mathrm{~mL}$ water sample to a $\mathrm{pH}$ of ca. 2.0 with $2 \mathrm{~mL}$ of $0.5 \mathrm{~N} \mathrm{HCl}$ in situ, introducing $13 \mathrm{~mL}$ of headspace to the syringe. We then shook the syringe for $2 \mathrm{~min}$ to equilibrate gasses in the acidified sample with the $13 \mathrm{~mL}$ of ambient-air headspace. After extracting $10 \mathrm{~mL}$ of the headspace into a separate airtight syringe, we detected both $\mathrm{CO}_{2}$ and TIC as $\mathrm{CO}_{2}$ within $48 \mathrm{~h}$ on a SRI $8610 \mathrm{C}$ gas chromatograph $\left(0.5 \mathrm{~mL}\right.$ sample loop, $105^{\circ} \mathrm{C}$ column temperature). Partial pressures of $\mathrm{CO}_{2}$ and TIC in pore water were calculated from headspace concentrations after Åberg and Wallin (2014) by subtracting ambient air additions, applying the Bunsen solubility coefficient and ideal gas law, and accounting for $\mathrm{pH}$ and water temperature concurrently measured in the field.

We tested whether sediment boxes differed from lake bottom samples in $\mathrm{pH}$ and log-transformed concentrations of each of DOC, TIC, and $\mathrm{CO}_{2}$ using linear mixed effects models fitted with restricted maximum likelihood. The models accounted for random variation from repeated measurements of individual syringes and sampling dates with sample type, either natural or artificial sediment, as a fixed explanatory effect. We then calculated $95 \%$ confidence intervals (CIs) from the fitted likelihood profiles and considered sediment boxes to differ from lake bottoms for a given response if the $95 \% \mathrm{CI}$ for their effect excluded zero. All analyses were carried out with the lme4 package in R v3.2.

We found that sediment boxes reproduced DOC and $\mathrm{pH}$ trends observed in pore waters of natural lake sediments with similar OM composition one year after installation, but had slightly more TIC and $\mathrm{CO}_{2}$ (Fig. 2). Over a 14-day period, DOC and $\mathrm{pH}$ in sediment boxes were indistinguishable from lake bottoms $(95 \%$ CI for difference: -0.73 to $1.21 \mathrm{mg} \mathrm{L}^{-1}$ and -0.05 to 0.22 , respectively; black points overlapping grey polygons in Fig. 2 a,b). By contrast, TIC, which was mostly comprised of $\mathrm{CO}_{2}$ (compare Fig. 2c and 2d), and $\mathrm{CO}_{2}$ itself were 0.63 to $5.88 \mathrm{mg} \mathrm{L}^{-1}$ and 0.33 to $3.97 \mathrm{mg} \mathrm{L}^{-1}$ higher in the sediment boxes, respectively. Nonetheless, temporal trends in box TIC and $\mathrm{CO}_{2}$ generally mirrored those in lake bottoms (Fig. 2 c,d).

We also compared zooplankton biomass between the natural surface sediments and sediment boxes studied for pore water in Lake Laurentian. Vertically-migrating animals were collected on two nights toward the end of our pore water sampling using a 500-mL funnel trap deployed at a height of $5 \mathrm{~cm}$ above the centre of each sediment sample as in Tanentzap et al., (2014). Traps were collected the morning after deployment, immediately filtered through an $80-\mu \mathrm{m}$ mesh, and live-sorted into pure zooplankton. To have sufficient mass for analyses, we pooled freeze-dried biomass between nights from the same trap. We then compared biomass between natural and artificial sediment using a linear model ( $l m$ function in R) with sample type as a fixed effect, while also accounting for sampling block, i.e. northerly or southerly exposure around the central dock (Fig. 3). Consistent with the pore water results, the mean $(95 \% \mathrm{CI})$ zooplankton biomass of 0.31 ( 0.23 to 0.43$) \mathrm{g} \mathrm{m}^{-2}$ sediment in the artificial boxes did not differ from the $0.31(0.22$ to 0.42$) \mathrm{g} \mathrm{m}^{-2}$ sediment in the natural lake bottoms with similar OM content ( $95 \%$ CI for difference: -0.13 to 0.09 $\mathrm{g} \mathrm{m}^{-2}$ sediment). 


\section{DISCUSSION}

We found a relatively close correspondence between natural and artificial sediments. While $\mathrm{CO}_{2}$ concentrations were slightly higher in our sediment boxes than adjacent lake bottoms, this likely reflects the more labile nature of the fresher tOM amendments. Labile tOM can be more quickly turned over through microbial biomass, elevating heterotrophic respiration and DOC production, the latter of which primes additional microbial activity, without necessarily increasing DOC concentrations (Bengtson and Bengtsson, 2007). We also found that littoral zooplankton occurred at similar standing biomass in natural and artificial sediments, although the colonisation of organisms larger than $1000 \mu \mathrm{m}$ could have been limited by the mesh above each sediment box. Future work will now need to test whether these mesocosms similarly reflect other geochemical and biological variables in neighbouring lake bottoms (Dzialowski et al., 2014), such as nitrogen fluxes and bacterial composition. Previous work with artificial sediments suggests that contained microbial communities may be less diverse (Goedkoop et al., 2005), but has not attempted to replicate natural conditions as we have done here.

Field experiments aim to apply a perturbation to natural assemblages of organisms and generalise the findings, often across larger spatial and temporal scales (Pace, 2001). Our method aids this process by allowing us to consider biogeochemical and ecological dynamics in sediments and benthic habitats with greater realism than previously possible. For example, we found that we could recreate natural DOC concentrations in sediment pore water. This finding is important because whole-ecosystem experiments have differed from smaller lab-based incubations in estimates of DOC dynamics (Zwart et al., 2016). Our method may therefore bridge contrasting approaches to studying lake sediments, i.e. lab vs whole ecosystem. Of course, our sediment boxes have caveats just like any other approach. First, there is an issue of scale and whether $\mathrm{C}$ dynamics across a $0.19 \mathrm{~m}^{2}$ box can mirror those across the whole $>50,000 \mathrm{~m}^{2}$ area of littoral sediment in lakes such as Lake Laurentian. Second, container walls have been shown to promote periphyton
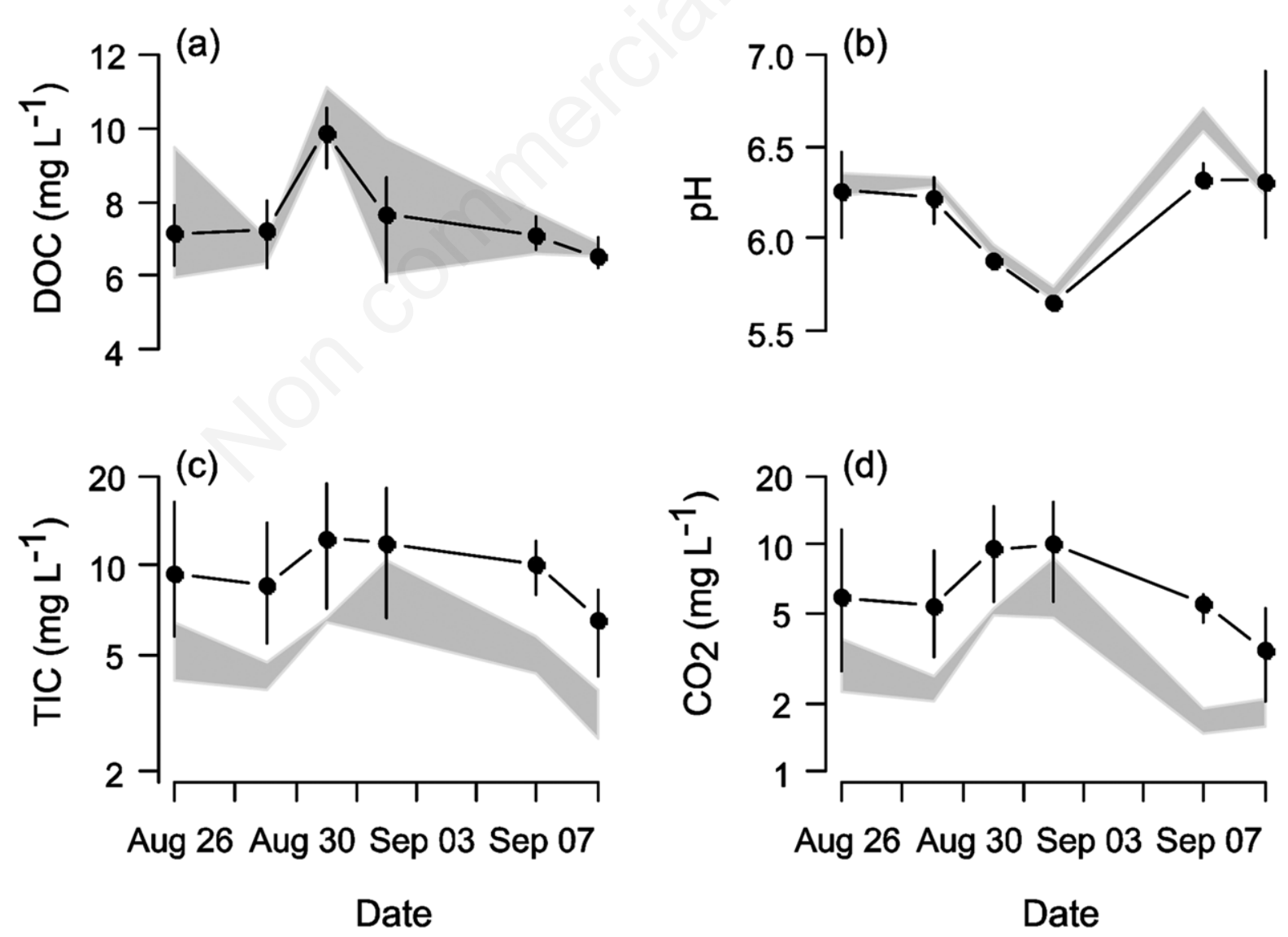

Fig. 2. Pore water chemistry in sediment boxes and their surrounding lake sediment during late summer 2016. a) DOC concentrations. b) $\mathrm{pH}$. c) TIC concentrations. d) dissolved $\mathrm{CO}_{2}$ concentrations. Black points are means, with vertical bars denoting the range of observations, in $n=3$ sediment boxes. Grey polygon is range of values in $n=3$ samplers installed in surrounding lake bottoms. 


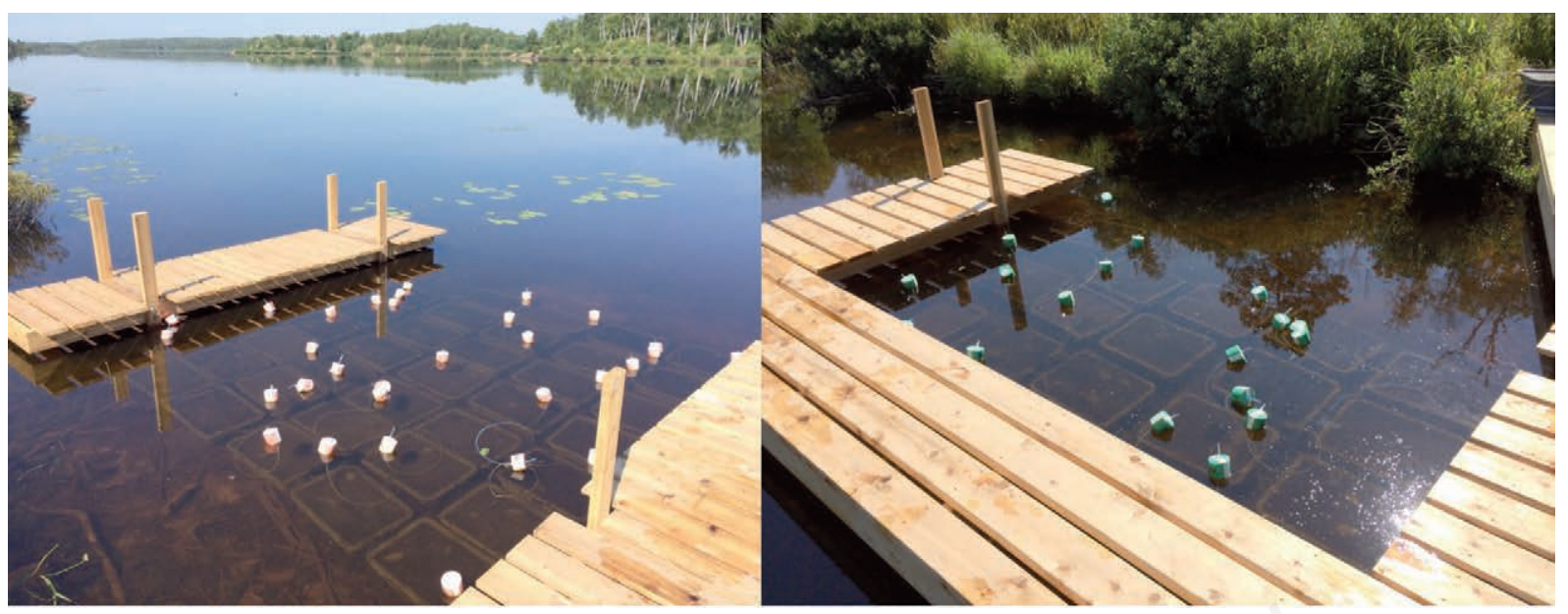

Fig. 3. Lake Laurentian study site with sediment boxes randomly deployed in a block design around three sampling docks. Left: view into lake from one sampling bay. Right: view into shore from other sampling bay.

growth and shift community composition (Chen and Kemp, 2004). We routinely cleaned container walls to minimise such effects, but have not quantified them as such. Container depth and surface area could also be reduced to minimise this wall effect, but at the cost of biological realism. Finally, all of our tOM amendments had a similar age. This differs from natural sediments where the same concentration of $\mathrm{OM}$ as in our boxes has accumulated over many years (Heathcote et al., 2015). Amending sediments with tOM also bypasses the priming and inoculation of material with microorganisms as it is exported from land into receiving waters. We tried to account for some of this priming by pre-soaking sediments with water from the study lake, which should have bacterial communities that reflect broader flow networks (RuizGonzález et al., 2015).

\section{CONCLUSIONS}

Here we have described a new experimental approach for studying the biogeochemistry and ecology of freshwater sediments at high spatial and temporal resolution. We have also shown that this method successfully mirrors both the absolute concentrations and temporal dynamics of biogeochemical parameters, especially those involved in carbon cycling, of natural sediments with similar organic matter inputs. Encouraged by our comparisons with natural lake bottoms, we believe that our method offers a way for better predicting how the important functions performed by lake sediments might respond to a changing world.

\section{ACKNOWLEDGMENTS}

This work was supported by NERC Standard Grant NE/L006561/1. We thank the many undergraduate students that spent their summer mulching, sieving, and collecting leaves for our boxes, as well as assisting with daily sampling, and two anonymous reviewers for improving an earlier draft. We are also indebted to Conservation Sudbury for allowing us to carry out our experiment in Lake Laurentian.

\section{REFERENCES}

Åberg J, Wallin MB, 2014. Evaluating a fast headspace method for measuring DIC and subsequent calculation of $\mathrm{pCO} 2$ in freshwater systems. Inland Waters 4:157-166.

Ask J, Karlsson J, Persson L, Ask P, Byström P, Jansson M, 2009. Whole-lake estimates of carbon flux through algae and bacteria in benthic and pelagic habitats of clear-water lakes. Ecology 90:1923-1932.

Bastviken D, Cole J, Pace M, Tranvik L, 2004. Methane emissions from lakes: Dependence of lake characteristics, two regional assessments, and a global estimate. Global Biogeochem. Cy. 18:GB4009.

Bengtson P, Bengtsson G, 2007. Rapid turnover of DOC in temperate forests accounts for increased $\mathrm{CO}_{2}$ production at elevated temperatures. Ecol. Lett. 10:783-790.

Bertolin A, Rudello D, Ugo P, 1995. A new device for in-situ pore-water sampling. Mar. Chem. 49:233-239.

Carignan R, 1984. Interstitial water sampling by dialysis: Methodological notes. Limnol. Oceanogr. 29:667-670.

Carpenter SR, 2005. Eutrophication of aquatic ecosystems: 
bistability and soil phosphorus. P. Natl. Acad. Sci. USA 102:10002-10005.

Chen C, Kemp WM, 2004. Periphyton communities in experimental marine ecosystems: scaling the effects of removal from container walls. Mar. Ecol. Prog. Ser. 271:27-41.

Costantini ML, Rossi L, Fazi S, Rossi D, 2009. Detritus accumulation and decomposition in a coastal lake (Acquatinasouthern Italy). Aquatic Conserv. 19:566-574.

Dzialowski AR, Rzepecki M, Kostrzewska-Szlakowska I, Kalinowska K, Palash A, Lennon JT, 2014. Are the abiotic and biotic characteristics of aquatic mesocosms representative of in situ conditions? J. Limnol. 73:603-612.

Eggleton J, Thomas KV, 2004. A review of factors affecting the release and bioavailability of contaminants during sediment disturbance events. Environ. Int. 30:973-980.

Feuchtmayr H, Moran R, Hatton K, Connor L, Heyes T, Moss B, Harvey I, Atkinson D, 2009. Global warming and eutrophication: effects on water chemistry and autotrophic communities in experimental hypertrophic shallow lake mesocosms. J. Appl. Ecol. 46:713-723.

Fischer H, Pusch M, 2001. Comparison of bacterial production in sediments, epiphyton and the pelagic zone of a lowland river. Freshwater Biol. 46:1335-1348.

Goedkoop W, Widenfalk A, Haglund A-L, Steger K, Bertilsson S, 2005. Microbial characterization of artificial sediment and comparisons with natural sediments -implication for toxicity testing. Environ. Toxicol. Chem. 24:2725-2733.

Håkanson L, Jansson M, 1983. Principles of lake sedimentology. Springer, Berlin: $360 \mathrm{pp}$.

Heathcote AJ, Anderson NJ, Prairie YT, Engstrom DR, del Giorgio PA, 2015. Large increases in carbon burial in northern lakes during the Anthropocene. Nat. Comm. 6:10016.

Herbst GN, 1980. Effects of burial on food value and consumption of leaf detritus by aquatic invertebrates in a lowland forest stream. Oikos 35:411-424.

Hoover TM, Marczak LB, Richardson JS, Yonemitsu N, 2010. Transport and settlement of organic matter in small streams. Freshwater Biol. 55:436-449.

Jackson CR, Foreman CM, Sinsabaugh RL, 1995. Microbial enzyme activities as indicators of organic matter processing rates in a Lake Erie coastal wetland. Freshwater Biol. 34:329-342

Korsman T, Nilsson MB, Landgren K, Renberg I, 1999. Spatial variability in surface sediment composition characterised by near-infrared, NIR reflectance spectroscopy. J. Paleolimnol. 21:61-71

Liboriussen L, Lauridsen TL, Søndergaard M, Landkildehus F, Søndergaard M, Larsen SE, Jeppesen E, 2011. Effects of warming and nutrients on sediment community respiration in shallow lakes: an outdoor mesocosm experiment. Freshwater Biol. 56:437-447.

Longhi D, Bartoli M, Viaroli P, 2008. Decomposition of four macrophytes in wetland sediments: Organic matter and nutrient decay and associated benthic processes. Aquat. Bot. 89:303-310.

Marmonier P, Piscart C, Sarriquet PE, Azam D, Chauvet E, 2010. Relevance of large litter bag burial for the study of leaf breakdown in the hyporheic zone. Hydrobiologia 641:203-214.
Orihel DM, Rooney RC, 2012. A field-based technique for sediment incubation experiments. J. Limnol. 71:233-235.

Pace ML, 2001. Getting it right and wrong: extrapolations across experimental scales, p. 161-181. In: R. H. Gardner, W. M. Kemp, V. S. Kennedy, J. E. Petersen (eds.), Scaling relations in experimental ecology. Columbia University Press.

Pace ML, Prairie YT, 2005.Respiration in lakes, p. 103-121. In: P. A. del Giorgio, P. J. le B. Williams (eds.), Respiration in aquatic ecosystems. Oxford University Press.

Peterson SA, 1982. Lake restoration by sediment removal. J. Am. Water Resour. As. 18:423-436.

Rasmussen JB, Godbout L, Schallenberg M, 1989. The humic content of lake water and watershed and lake morphometry. Limnol. Oceanogr. 34:1336-1343.

Ruiz-González C, Niño-García JP, del Giorgio PA, 2015. Terrestrial origin of bacterial communities in complex boreal freshwater networks. Ecol. Lett. 18:1198-1206.

Song N, Yan Z-S, Cai H-Y, Jiang H-L, 2013. Effect of temperature on submerged macrophyte litter decomposition within sediments from a large shallow and subtropical freshwater lake. Hydrobiologia 714:131-144.

Suedel BC, Rodgers JH, 1994. Development of formulated reference sediments for freshwater and estuarine sediment testing. Environ. Toxicol. Chem. 13:1163-1175.

Swerhone GDW, Lawrence JR, Richards JG, Hendry MJ, 1999. Construction and testing of a durable platinum Eh electrode for in-situ redox measurements in the subsurface. Groundwater Monitoring and Remediation 19: 132-136.

Tanentzap AJ, Szkokan-Emilson EJ, Kielstra BW, Arts MT, Yan ND, Gunn JM, 2014. Forests fuel fish growth in freshwater deltas. Nat. Comm. 5:4077.

Tranvik LJ, Downing JA, Cotner JB, Loiselle SA, Striegl RG, Ballatore TJ, Dillon P, Finlay K, Fortino K, Knoll LB, Kortelainen PL, Kutser T, Larsen S, Laurion I, Leech DM, McCallister SL, McKnight DM, Melack JM, Overholt E, Porter JA, Prairie Y, Renwick WH, Roland F, Sherman BS, Schindler DW, Sobek S, Tremblay A, Vanni MJ, Verschoor AM, von Wachenfeldt E, Weyhenmeyer GA, 2009. Lakes and reservoirs as regulators of carbon cycling and climate. Limnol. Oceanogr. 54:2298-2314.

Vadeboncoeur Y, Zanden MJV, Lodge DM, 2002. Putting the lake back together: reintegrating benthic pathways into lake food web models. BioScience 52:44-54.

Wetzel RG, 2001. Limnology: lake and river ecosystems. Gulf Professional Publishing, Oxford: 1006 pp.

Wood SLR, Richardson JS, 2009. Impact of sediment and nutrient inputs on growth and survival of tadpoles of the Western Toad. Freshwater Biol. 54:1120-1134.

Wurzbacher CM, Barlocher F, Grossart HP, 2010. Fungi in lake ecosystems. Aquat. Microb. Ecol. 59:125-149.

Yu ZT, Wang XJ, Zhang EL, Zhao CY, Liu XQ, 2015. Spatial distribution and sources of organic carbon in the surface sediment of Bosten Lake, China. Biogeosciences 12:66056615.

Zwart JA, Craig N, Kelly PT, Sebestyen SD, Solomon CT, Weidel BC, Jones SE, 2016. Metabolic and physiochemical responses to a whole-lake experimental increase in dissolved organic carbon in a north-temperate lake. Limnol. Oceanogr. 61:723-734 